\title{
MODEL RESOLUSI KONFLIK ALTERNATIF DALAM HUKUM ISLAM
}

\author{
Ahwan Fanani \\ IAIN Walisongo Semarang \\ Jl. Walisongo No. 3-5 Semarang 50185 \\ Email: aristofanfanani@yahoo.com
}

\begin{abstract}
Abstrak
Hukum Islam sering dipandang sebagai hukum yang keras dan agresif. Pandangan demikian tidak hanya dianut oleh kalangan nonmuslim, namun juga oleh sebagian kalangan muslim sendiri. Mispersepsi mengenai sifat dasar hukum Islam tersebut sering mengaburkan mekanisme perdamaian yang ditawarkan oleh hukum Islam. Formulasi studi perdamaian dalam dunia Islam kurang berkembang, sehingga referensi terhadap mekanisme-mekanisme resolusi konflik dalam hukum Islam belum memenangkan wacana publik umat Islam, apalagi publik yang lebih luas. Tulisan ini adalah upaya untuk menggali model-model resolusi konflik alternatif dalam hukum Islam, baik dalam menghadapi konflik antara sesama muslim maupun dengan nonmuslim. Tulisan ini menunjukkan bahwa Islam memiliki model-model resolusi konflik alternatif, khususnya sly/h\}dan tahkim. Keduanya mewakili resolusi konflik alternatif yang banyak diacu dalam al-Quran maupun hadis. Kedua resolusi konflik alternatif tersebut mengandung elemen-elemen persamaan dengan beberapa model resolusi konflik alternatif modern, namun ada aspek-aspek khas yang membuat model resolusi konflik alternatif dalam Islam memiliki keunikan, yaitu memiliki basis agama dan lebih menekankan penyelesaian konflik bersama.
\end{abstract}

Kata kunci: resolusi konflik alternatif, perdamaian, hukum Islam, sylh\}?tahkim

\begin{abstract}
Islamic law is often seen as harsh and aggressive law. Such a view is not only shared by non-Muslims, but also by some Muslims themselves. Misperceptions about the nature of Islamic law are often obscuring peace mechanism offered by Islamic law. Formulation of peace studies in Islamic world is less developed, so that reference to mechanisms of conflict resolution in Islamic law has yet to win Muslim public discourse, let alone the wider public. This paper is an attempt to explore models of alternative dispute resolution in Islamic law, both in dealing with the conflict between the Muslim and non-Muslim neighbors. This paper shows that Islam has models of alternative dispute resolution, in particular sly/h\} and tahkim.. Both represent an alternative conflict resolution that is widely mentioned in the Qur'an and hadis. Both alternative conflict resolutions contain elements in common with some modern models of alternative dispute resolution, but there are aspects that make the alternative model of conflict resolution in Islam is unique, in which it has a religious basis, and it also more emphasizes to resolve a collective conflict.
\end{abstract}

Keywords: alternative conflict resolution, peace, Islamic law, sly/h\}tahlkim 


\section{A. Pendahuluan}

Syariat Islam $^{1}$ sering dicurigai mengandung bibit-bibit kekerasan dan legitimasi terhadap konflik. Kecurigaan terhadap bibit kekerasan dalam hukum Islam tersebut didasarkan atas beberapa produk hukum, seperti hukum rajam, hukum potong tangan, hukum cambuk, dan hukum mati bagi orang yang murtad. Contoh-contoh tersebut membuat hukum Islam mendapatkan reputasi sebagai hukum yang kejam. Reputasi hukum Islam sebagai hukum yang mengandung elemen kekerasan tidak hanya menimbulkan fobia di kalangan nonmuslim, bahkan di kalangan umat Islam sendiri. $^{2}$

Kecurigaan bahwa syariat Islam melegitimasi konflik didasarkan seringkali dilandaskan kepada ajaran jihad dalam fikih-fikih Islam. Bahasan jihad menjadi salah satu sub bahasan dalam kitab fikih standar, bersama dengan tema-tema ibadah, muamalah, munakahah, warisan, peradilan, pidana, sembelihan, dan makanan dan minuman. ${ }^{3}$ Namun seringkali terjadi salah pemaknaan tentang jihad sehingga jihad diasosiasikan dengan "perang suci", padahal tema jihad dalam fikih Islam sebenarnya mencakup segala persoalan yang terkait siyar, atau hukum internasional (law of nation) ${ }^{4}$ yang di dalamnya menyangkut persoalan kewarganegaraan, perdamaian, perang, dan perjanjian antara negara Islam dengan negara yang dikuasai nonmuslim. Hanya saja, istilah jihad kemudian mengalami berbagai pemaknaan, di antaranya yang mendukung konotasi konflik dan peperangan.

Akibat dari populernya wacana jihad dalam pengertian perang dan hukuman pidana tertentu yang dipandang keras, sumbangsih hukum Islam dalam penciptaan perdamaian akhirnya terabaikan. Sebagai landasan hukum yang digunakan berabad-abad oleh umat Islam, dengan beragam intensitas penerimaan terhadapnya, hukum Islam tidak dapat dipungkiri telah memainkan peran yang biasa diemban oleh hukum, yaitu sebagai sarana untuk mewujudkan keadilan dan sarana menciptakan ketertiban. Hal itu meniscayakan bahwa hukum Islam juga menyediakan perangkat untuk merealisasikan keadilan dan ketertiban.

Persoalannya adalah formulasi peace studies (studi perdamaian) dalam dunia Islam kurang berkembang. Akibatnya, referensi terhadap mekanisme-mekanisme resolusi konflik dalam hukum Islam sendiri belum memenangkan wacana publik umat Islam itu sendiri, apalagi publik yang lebih luas. Berbeda halnya dengan formulasi peace studies dalam tradisi keilmuan Barat modern. Peace studies dan resolusi konflik banyak dikaji dan dikembangkan di perguruan tinggi di Eropa dan Amerika sehingga melahirkan berbagai konsepsi dan praktek yang kaya. Mediasi, misalnya, telah berkembang sedemikian rupa sehingga melahirkan berbagai pendekatan, seperti mediasi fasilitatif, mediasi evaluatif, mediasi unity-based, mediasi naratif, mediasi transformatif, dan mediasi settlement. ${ }^{5}$ Belum lagi model-model resoluasi konflik lain, maupun pendekatan dalam peace-making, peace building, dan intervensi konflik lainnya. $^{6}$

Arti penting resolusi konflik saat ini mulai dirasakan umat Islam ketika dunia Islam mengalami hubungan tidak harmonis dengan dunia Barat. Isu radikalisme, terorisme, dan fundamentalisme yang diasosiasikan dengan gerakan-gerakan Islam mendorong akademisi muslim untuk mencoba meninjau dan mengangkat kembali resolusi konflik dan upaya perdamaian dalam ajaran Islam. Upaya tersebut dilakukan sebagai upaya untuk mengenal resolusi konflik dalam Islam dan melihat bagaimana Islam juga menyediakan model resolusi konflik dan memiliki kontribusi pagi upaya perdamaian. ${ }^{7}$ 
Namun beberapa upaya pengkajian resolusi konflik dalam Islam tersebut masih menekankan kepada penemuan nilai-nilai perdamaian dalam Islam. Hal itu bisa menjadi langkah awal bagi pengenalan resolusi konflik dalam Islam, hanya saja kurang memiliki dimensi aplikatif. Dimensi resolusi konflik aplikatif dalam Islam tentu tidak bisa dipisahkan dari hukum Islam, yang memiliki spesifikasi obyek kajian perbuatan nyata umat Islam. Oleh karena itu, tulisan ini ditujukan untuk menggali model-model resolusi konflik dalam hulkum Islam,

Akan tetapi, jika resolusi konflik yang dimaksud adalah terkait dengan dunia peradilan, maka upaya penggaliannya akan kurang bernilai mengingat kajian mengenai peradilan Islam telah banyak dilakukan. Jadi, tulisan ini hanya akan berfokus kepada penemuan model-model resolusi konflik alternatif (ADR) dalam hukum Islam. Tujuan utama artikel ini adalah untuk memetakan model-model resolusi konflik alternatif dalam hukum Islam dan membandingkannya dengan model-model resolusi konflik modern agar modelmodel resolusi Islam dapat terapresiasi ciri khas yang dimilikinya. Untuk melihat keunikan resolusi konflik dalam hukum Islam, konsep-konsep resolusi konflik modern bertindak sebagai kacamata untuk menilainya.

\section{B. Resolusi Konflik dalam Hukum Islam}

Konsep, nilai dasar, dan mekanisme resolusi konflik dalam hukum Islam sebenarnya bisa dilacak prototipnya dalam dua sumber utama hukum Islam, yaitu al-Qur'an dan sunnah. Konsepkonsep perdamaian dalam hukum Islam dapat dipahami dengan melihat ajaranajaran perdamaian dalam al-Qur'an dan praktek Nabi Muhammad dalam menyikapi konflik atau sengketa. Kedua sumber hukum tersebut menjadi legitimasi dan inspirasi bagi pengembangan resolusi konflik dalam hukum Islam.

Al-Qur'an mengajarkan konsepkonsep perdamaian seperti salam (mengucapkan atau merealisasikan keselamatan), 'afw (permaafan), is/ah (mendamaikan), dan aman (memberikan jaminan keamanan bagi orang lain). Surat al-Furqan ayat 63, misalnya, mengajarkan prinsip rendah hati dan menghindari provokasi: "Adapun hamba-hamba Tuhan Yang Maha Pengasih itu adalah orangorang yang berjuang di bumi dengan rendah hati dan apabila orang-orang bodoh menyapa mereka (dengan katakata menghina), mereka mengucapkan salam." Ayat tersebut menunjukkan bahwa sikap yang harus diambil umat Islam terhadap provokasi adalah dengan mengucapkan salam. Sikap al-Qur'an tersebut dalam konteks resolusi konflik bisa dibaca dalam dua pengertian, yaitu 1) bahwa umat Islam diminta untuk menghindari kekerasan dan konflik dan 2) umat Islam aktif dalam menyebarkan dan merealisasikan perdamaian.

Dimensi konstruktif dalam mekanisme resolusi konflik umat Islam tersebut didukung pula oleh dua ayat berikut, yaitu al-Zukhruf ayat 89 dan alMukminun ayat 96. Surat al-Zukhruf ayat 89 menyatakan bahwa orang-orang yang berpengetahuan umat Islam diminta untuk menghindari orang-orang yang ....

$$
\text { فَاصْفَحْ عَنْهُمْ وَ قُلْ سَلَاُْ. فَسَوْفَ يَعْلَمُمْنَ. }
$$

Sebaliknya, pada ayat kedua ada perintah untuk menolak perilaku buruk dari pihak lain dengan perbuatan baik. Ayat kedua tersebut menekankan dimensi prevensi dan rekonsiliasi dalam menyikapi konflik.

Prinsip-prinsip perdamaian dalam al-Qur'an merentang juga mulai dari memaafkan, bermusyawarah, bertabayyun (klarifikasi), hingga ajakan untuk mencari model hubungan bersama. Al-Qur'an juga memuji orang-orang yang suka melakukan upaya islak\} (mendamaikan). 
Sunnah Nabi Muhammad juga meletekkan landasan bagi mekanisme resolusi konflik. Nabi Muhammad dikenal sebagai arbitrator atau mediator yang sukses. Ia mendapat gelar al-Amin (yang dapat dipercaya) karena kemampuannya untuk mendamaikan kelompok-kelompok yang bertikai dan mampu menciptakan mekanisme perdamaian melalui piagam Madinah. ${ }^{8}$

Dari preseden-preseden itulah, model resolusi konflik dikembangkan dalam hukum Islam sebagai bagian dari penciptaan keadilan dan ketertiban sosial. Hukum Islam diakui telah memainkan peran penting dalam menggeser orientasi hukum masyarakat Arab yang didasarkan kepada tradisi dan kebiasaan menuju ke dalam sistem hukum yang lebih mapan. Al-Qur'an adalah pilar dari perubahan otoritas hukum dari para pemimpin tradisional, yaitu syekh dan kahin, kepada para sahabat yang memiliki kemampuan memahami wahyu. Otoritas yang didasarkan atas kemampuan memahami teks wahyu tersebut oleh Wael B. Hallaq disebut sebagai otoritas epistemis. ${ }^{9}$

Otoritas epistemis tersebut umumnya dimiliki oleh para sahabat karena kedekatan mereka dengan shbib al-syarisah (Nabi Muhammad) dan kedekatan mereka dengan konteks turunnya wahyu. Oleh karena itu, para sahabat ada yang ditugasi untuk memutuskan persengkataan, baik di Makkah, Madinah, maupun Yaman. ${ }^{10}$ Hakim atau qadli memainkan peran sentral bagi resolusi konflik, khususnya dalam bidang-bidang perdata. Para hakim dipilih di kalangan ulama yang memiliki kecakapan hukum yang mumpuni, sehingga ada yang mensyaratkan bahwa hakim adalah mujtahid.

Tidak hanya peradilan, Nabi Muhammad dan para sahabat juga mempraktekkan model-model resolusi konflik. Sebagian model resolusi konflik yang dipraktekkan Nabi Muhammad dan para sahabat berasal dari dalam tradisi hukum Islam terdapat beberapa model resolusi konflik yang patut direvitalisasi. Model-model resolusi konflik dalam hukum Islam tersebut bisa memperkaya model resolusi konflik yang ada saat ini. Di antara model-model resolusi konflik yang dikenal dalam hukum Islam antara lain adalah sly/h, tahkim, hudnah, dan akad aman. Boleh jadi model-model resolusi konflik yang dalam hukum Islam lebih banyak dari empat tersebut, tetapi empat model tersebut bisa menjadi contoh resolusi konflik dalam hukum Islam.

\section{1. $S\{1 / h\}$}

$S$ \&́lh hadalah model resolusi konflik yang banyak disebut-sebut dalam alQur'an dan digunakan dalam hukum Islam. Secara bahasa sly/h\} berarti menyelesaikan persengketaan. Adapun menurut istilah $s$ ly/h\}berarti akad yang menghentikan permusuhan atau perselisihan. ${ }^{11}$ Definisi tersebut muncul dalam tema pembahasan $s$ ly/h\} sebagai upaya penyelesaian konflik dalam bidang muamalah atau perhubungan harta. Akan tetapi, penggunaan sly/h\} sendiri sebenarnya jauh lebih luas dari sekedar resolusi konflik dalam kasus konflik masalah harta.

Ibnu Qudamah, misalnya, memetakan berbagai ragam sly/h\}dalam hukum Islam. Ia mengemukakan tiga ragam $s$ ly/h $\}$ yaitu 1) $s$ l $/ h$ h $\}$ antara umat Islam dengan ahl al-härb (kekuasaan nonmuslim yang tidak memiliki perjanjian dan terlibat konflik dengan umat Islam), 2) sly/h \}antara pihak yang adil (ahl al-'adl) dan pihak yang makar (ahl al-baghy), dan 3) sly/h/antara suami dan isteri. ${ }^{12}$ Sementara itu, al-Ramli> mengemukakan empat ragam sly/h $\}$ dalam hukum Islam, yaitu 1) sly/h \}antara umat Islam dan kaum kafir, 2) sly/h\} antara pimpinan dan pemberontak, 3) sly/h\} antara suami isteri ketika terjadi syiqae, ${ }^{13}$ dan 4) $s$ l $/ h$ h dalam bidang muamalah. ${ }^{14}$ Selain itu, Sahnup, seorang tokoh Malikiyyah, mengemukakan ragam lain $s \quad l / h\}$ yaitu $s|l| h\}$ dalam kasus pidana pembunuhan. ${ }^{15}$ Hal yang sama juga 
dikemukakan oleh Wahbah Zuhayli> Wahbah memasukkan sly/h\}dalam kasus kasus pembunuhan yang disengaja maupun tidak disengaja sebagai bagian dari $s$ ly/h.\} Ia bahkan menambahkan satu bentuk $s, y / h$ \& yaitu $s \xi y / h$ lantara umat Islam dengan ahl al-hq̈rb dengan akad z/mmah, hudnah, dan amax. ${ }^{16}$

Jadi, obyek sly/h\}bisa menyangkut persoalan hubungan kenegaraan, hubungan antarkomunitas, dan sampai persoalan interpersonal. Itu berarti $s(l) / h\}$ menjadi semacam model resolusi konflik multifungsi, yang bisa digunakan untuk konflik level interpersonal, komunal, dalam negeri (intrastate), maupun antarnegara. Syl/h\}yang disebutkan dalam al-Qur'an dan hadis pun mencakup levellevel konflik konflik-konflik komunal maupun konflik interpersonal. ${ }^{17}$ Di ragam $s l y / h\}$ yang dikenal dalam tradisi hukum Islam antara lain:

Pertama, sly/h\} dalam konflik interpersonal dalam konteks konflik keluarga. S\{l/h\} semacam ini dalam Alquran dikaitkan dengan adanya nusyuz kedurhakaan salah satu pihak. ${ }^{18} S$ ly/h $\}$ tersebut menariknya berlaku dalam konteks nusyuz (kedurhakaan) yang dilakukan oleh suami. Umumnya, nusyuæ diasosiasikan dengan perilaku isteri yang membuat suami harus mengambil langkah-langkah: 1) menasehati, 2) berpisah ranjang, 3) atau memukul isterinya. ${ }^{19}$ Namun $\left.s, y / h\right\}$ dalam surat al$\mathrm{Nisa}>$ ayat 128 tersebut justru berlaku terkait dengan nusyuz seorang suami, yaitu terkait dengan keinginan suami untuk mengabaikan atau bahkan menceraikan isteri karena isteri sakit, tua, atau berwajah buruk.

Menurut Sayyid Sabiq, sly/h\}dalam konteks nusyuz itu berupa pelepasan sebagian hak isteri untuk menyenangkan pihak suami. Sabiq mendasarkan pemahaman tersebut kepada komentar
'A isyah, dalam hadis riwayat al-Bukhaæi> yang menyatakan bahwa maksud surat al$\mathrm{Nisa}$ ' ayat 128 adalah mengenai isteri yang hendak dicerai oleh suaminya. Perempuan tersebut kemudian meminta suaminya agar tidak menceraikan dengan kompensasi bahwa laki-laki itu tidak perlu memberi nafkah dan giliran kepadanya. $^{20}$ Namun pelepasan hak nafkah dan giliran itu bukan pilihan ideal dalam sly/h.\} Contoh ideal $s \mid l / h$ \} menurut Ibn Qayyim, adalah sly/hyyang dilakukan oleh Saudah binti Zam'ah. ${ }^{21}$ Alasan Ibn Qayyim adalah bahwa laki-laki memiliki hak untuk menceraikan isteri dan menikah lagi. Ketika isteri melepaskan sebagian haknya guna mempertahankan sebagian hak lainnya, maka perdamaian semacam itu ia pandang sebagai sly/h\} yang adil. ${ }^{22}$

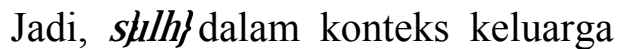
ini merupakan bentuk pelepasan hak atau kompensasi yang diberikan isteri kepada suami untuk tetap mempertahankan keutuhan rumah tangga. Sly/h\} dalam konteks keluarga ini lebih menunjukkan upaya pihak isteri untuk mencegah terjadinya perceraian atau kerugian yang lebih besar yang ia peroleh akibat perceraian dengan memberikan izin suami menikah kembali, bahkan disertai dengan pelepasan hak nafkah atau hak atas giliran. Sly/h\} dengan pelepasan sebagian hak atau pemberian kompensasi itu juga menjadi landasan bagi sly/h lalam kasus sengketa harta.

$S \not l / h$ \} semacam ini merefleksikan pula bentuk negosisasi, khususnya negosiasi distributif. Para pihak melakukan perdamaian secara kompromi dengan melepaskan sebagian posisi atau tuntutan mereka untuk mendapatkan sebagian posisi/tuntutan lainnya. Logika negosiasi tersebut dapat digambarkan dalam ilustrasi berikut: 
Bagan 1

Contoh Negosiasi Distributif dalam Kasus Perceraian

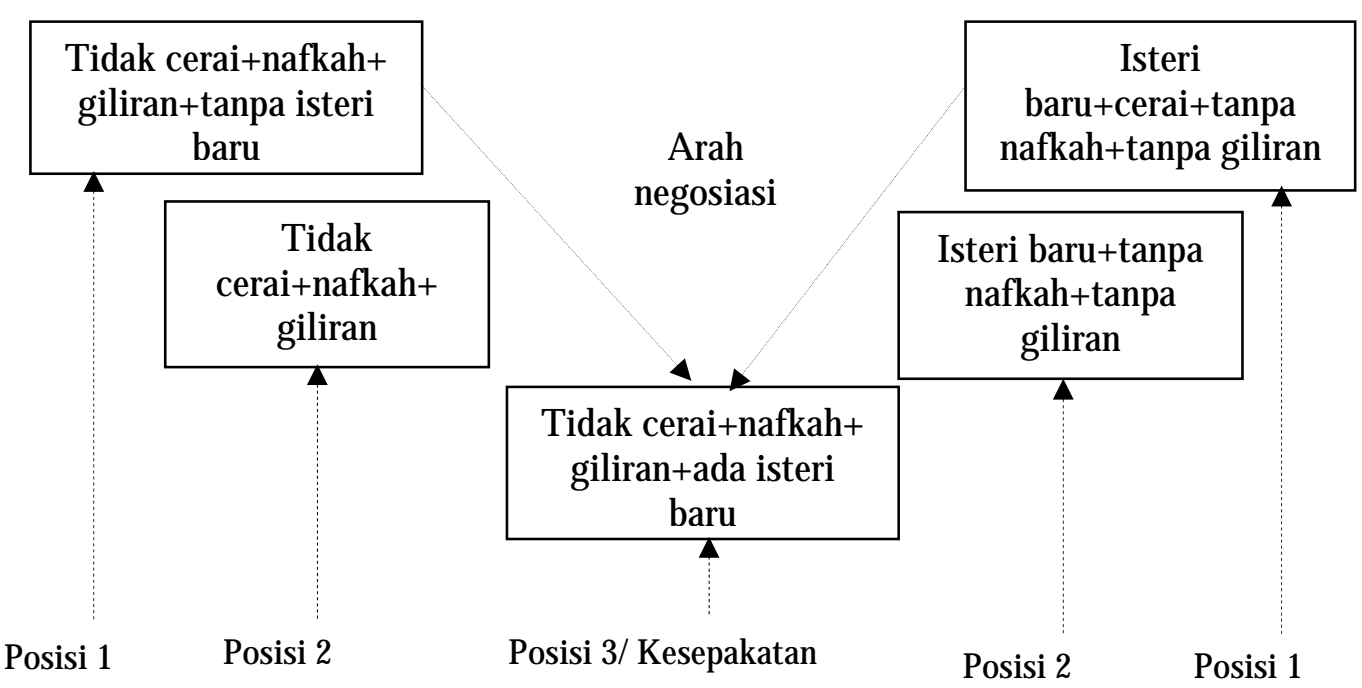

Ilustrasi di atas menunjukkan bahwa kesepakatan dalam sll/h\}negosasi secara distributif bergerak dari tuntutan/posisi maksimal, menuju kesepakatan dengan tuntutan/posisi yang diterima kedua belah pihak. Jadi, perdamaian adalah kompromi dari dua posisi yang bertentangan yang berakhir dengan jalan tengah dengan kedua belah pihak turun dari garis posisi maksimal (upperline) menuju area kesepakatan.

Kedua, syl/h\}dalam kasus perdata mengenai harta. Sylh \}ini menjadi bahan bahasan baku dalam kitab-kitab fikih standar pada bab muamalah. Sy/h)dibahas bersama dengan jual beli, pinjam meminjam, gadai, sewa menyewa, kerja sama, dan lainnya. Landasan normatif bagi keberadaan $s$ ly/hłlalam konteks harta tersebut antara lain adalah hadis yang populer di kalangan ahli fikih: "Sly/h\} boleh dilakukan antara kaum muslimin, kecuali $s: 4 / h\}$ yang menghalalkan yang haram dan mengharamkan yang halal." 23 Meskipun hadis tersebut berbicara dalam hubungan sesama muslim, namun para ulama fikih berpendapat bahwa hubungan perdata nonmuslim pun bisa berlaku juga sly/h.\}

Syl/h\}dalam hubungan harta bisa memiliki konsekuensi yang akad jual beli, shuf'ah, atau ija®ah. ${ }^{24}$ Sylh \}dengan akad mirip jual beli terjadi ketika terjadi aib dalam jual beli sehingga pembeli meminta ganti barang. Namun sly/h\}ini tidak bisa disebut dengan jual beli karena jual beli tidak didahului dengan sengketa, sementara $s \xi l / h\}$ didahului sengketa mengenai barang yang dibeli. ${ }^{25} S\{l / h\}$ dalam bidang hutang piutang terjadi bisa melalui pelepasan sebagian hak. Preseden sly/h\} dalam hutang piutang tersebut disebutkan dalam hadis Bukhari dan Muslim dari Ka'b bin Malik RA. Diceritakan bahwa Ka'b ibn Malik menagih hutang Abdullah ibn Abi> Hadrad di masjid. Mereka bersengkata dengan suara keras hingga terdengar oleh Rasulullah yang berada dalam rumahnya. Rasulullah lalu keluar rumah sampai terbuka penutup pintu kamarnya, lalu memanggil $\mathrm{Ka}^{\mathrm{b}} \mathrm{b}$ dan meminta $\mathrm{Ka}^{\mathrm{c}} \mathrm{b}$ untuk menggugurkan separuh hutangnya dan $\mathrm{Ka}$ 'b setuju. ${ }^{26}$

Hadis tersebut menunjukkan sebuah pelepasan hak untuk mencapai perdamaian. Proses tersebut bisa diinisiasi oleh pihak ketiga, sebagaimana tampak dalam hadis di atas. Namun sly/h\} tidak harus dalam bentuk pelepasan hak, melainkan bisa pula dalam bentuk reparasi atau jasa pengganti, yang semua 
itu bisa berlaku dalam berbagai akad. Sewa menyewa pun bisa dilakukan $s$ ly/h\} dengan, misalnya, meminta penyewa memperbaiki rumah yang rusak akibat dipakai oleh penyewa atau dengan pelayanan tertentu yang diminta oleh salah satu pihak.

Ketiga, sly/hłdalam konteks pidana pembunuhan. Syl/h\}dalam konteks pidana merupakan konsepsi khas dalam hukum Islam. Hal itu terjadi karena dalam Islam perbuatan pidana pembunuhan memiliki dimensi pidana dan dimensi perdata. Pilihan hukuman terhadap pembunuh bisa berupa qis $\mathbf{f} 8\}$ (hukuman sepadan dengan perbuatannya) atau bisa juga melalui pemberian maaf, yang berkonsekuensi dengan pembayaran diyat atau tanpa diyat. Dasar hukum pemberian maaf tersebut dalam dalam surat al-Baqarah 178.

Ayat tersebut menurut Ibn 'A bbas turun terkait dengan pembunuhan sengaja. Pembunuhan sengaja membolehkan repentensi yang lebih banyak, setara, atau sama dengan jumlah diyat. Sebaliknya, dalam pembunuhan tersalah (qatl al-khat ${ }^{\prime}$ ), penggantian tidak boleh lebih banyak dibandingkan jumlah diyat dengan pertimbangan bahwa diyat merupakan ketentuan syar'i dan qishs\} sendiri pada dasarnya bukan harta. $^{27}$

Sy/hłdalam kasus pembunuhan ini dalam perspektif resolusi konflik kontemporer bisa dikategorikan sebagai bentuk rekonsiliasi atau restorative justice. Gagasan utama rekonsiliasi dengan landasan restorative justice adalam pemulihan hubungan yang retak akibat konflik. Pembunuhan pada dasarnya hubungan interpersonal, namun dalam konteks masyarakat yang komunal pembunuhan bisa berujung kepada konflik komunal. Tidak jarang, upaya pembalasan terhadap pihak pelaku dilakukan secara proporsional sehingga yang terjadi adalah siklus kekerasan yang tidak berujung.

Oleh karena itu, tujuan akhir dari rekonsiliasi adalah terciptanya keadilan yang berorientasi kepada perbaikan hubungan, dari konflik menjadi tidak konflik, dari hubungan antargonistik menjadi hubungan kooperatif. Pilar dasar rekonsiliasi ada empat, yaitu penyembuhan/pemaafan, penceritaan kebenaran, reparasi, dan keadilan restoratif, sebagaimana tampak dalam bagan berikut: ${ }^{28}$

Bagan 2

Empat Elemen Rekonsiliasi

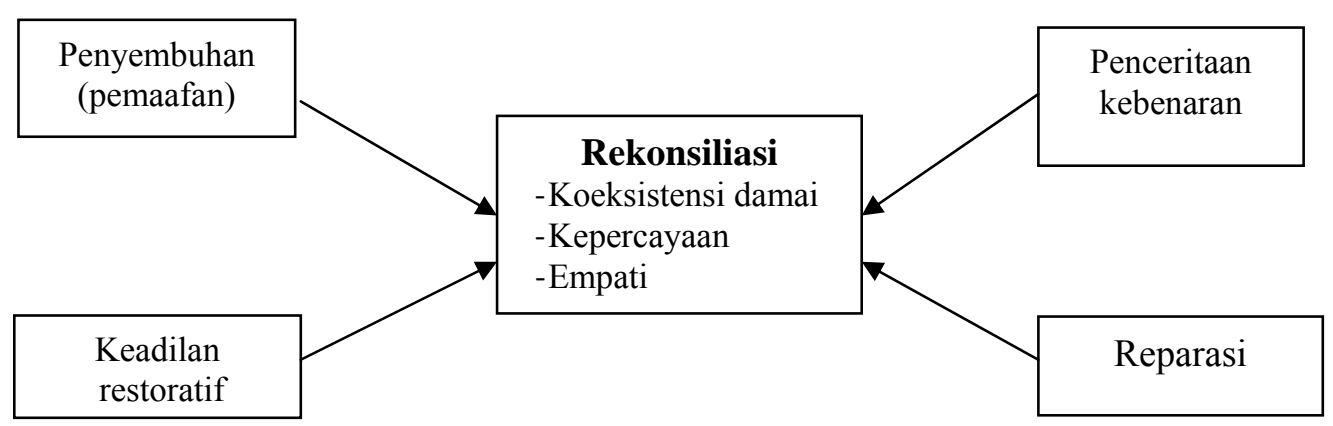

Gambar di atas menunjukkan bahwa pemaafan menjadi bagian rekonsiliasi yang terjadi setelah pelaku kekerasan mengakui kesalahannya. Pihak korban kemudian memaafkan sehingga tidak perlu lagi diperpanjang permasalahan dan kasus tidak perlu diajukan ke pangadilan. Sebagai kompensasi atas kerugian yang diderita oleh korban, pihak pelaku kekerasan 
diminta untuk membayar reparasi, yang bisa saja berupa benda material maupun nonmaterial.

Dalam hukum Islam pun, ketika terjadi sly/h/antara pihak keluarga korban pembunuhan dengan pelaku pembunuhan, maka kasus pembunuhan tersebut tidak lagi diajukan ke pengadilan. Kata kunci dari proses 5 l $/ / h\}$ dalam bidang pembunuhan adalah pengampunan dari pihak keluarga. Pengampunan tersebut, menurut al$M$ ardi> bisa memiliki tiga kemungkinan: 1) pengampunan terhadap qishs\}\}dan kewajiban membayar diyat, 2) pengampunan atas qisłs\} saja, dengan membayar diyat, 3) pengampunan secara umum. 29

Qisł8\}dalam konteks rekonsiliasi adalah bentuk keadilan retributif, yaitu keadilan dengan membalas kepada pelaku kejahatan dengan balasan yang setimpal. Sebaliknya, pengampunan berarti adalah bentuk restorative justice (keadilan restoratif), yang esensinya adalah penyelesaian konflik tanpa melalui pembalasan. Sementara itu, diyat merupakan bentuk reparasi atau konsekuensi yang bahwa pelaku kejahatan

pertanggungjawabnya menunjukkan memberikan ganti rugi kepada pihak korban. Hanya saja, sebagaimana disebutkan oleh al-M ardi cdi atas, baik qishs\})maupun reparasi tersebut menjadi pilihan pihak keluarga korban sehingga pihak keluarga korban bisa bisa meminta balasan, pengampunan dengan melalui reparasi, atau bahkan pengampunan tanpa konsekuensi apa pun.

Keempat, sly/h\} untuk menyelesaikan konflik komunal, khususnya konflik antara muslim dengan nonmuslim. disebutkan dalam surat al$\mathrm{H}$ \&jurabayat 9: "Jika dua golongan orang mukmin berperang, maka damaikanlah antara keduanya." ${ }^{30}$ Ayat tersebut menunjukkan slal/h\}ebagai model resolusi konflik dalam kasus konflik komunal atau antarkelompok. Sy/h\} bisa dilihat sebagai bentuk conflict settlement, peace keeping dan peace making.

$S y / h\}$ dalam pengertian tersebut lebih menekankan peran pihak ketiga untuk turut menghentikan pertikaian dan mencapai perdamaian, setidaknya dalam bentuk negative peace, yaitu perdamaian dalam konteks tidak ada lagi pertikaian fisik. Pihak ketiga dalam sly/h/ni menjadi mediator atau penengah di antara kelompok-kelompok yang bertikai. Namun peran pihak ketiga dalam sly/h\} untuk konflik komunal tergantung tidak harus sebagai pihak yang netral dan imparsial (tidak memihak). Ada kalanya pihak ketiga berubah menjadi posisi dari mediator kemudian menjadi advokat ketika salah satu pihak menolak untuk berdamai dan memilih untuk berbuat zalim kepada pihak lain. Pihak lalu mengubah peran dari fasilitator komunikasi menjadi aktor penyeimbang kekuatan agar upaya perdamaian (sly/h/ bisa dilakukan kembali.

Peranan sebagai penyeimbang kekuatan oleh pihak ketiga tersebut dijelaskan oleh Ibn Qayyim al-Jauziyyah dalam I'Iam al-M uwaqqi'ip. Ibn Qayyim menyatakan:

Allah pertama-tama memerintahkan untuk mendamaikan dua kelompok yang bertikai. Jika salah satu kelompok menganiaya kelompok yang lain, maka diperintahkan untuk memerangi kelompok yang aniaya, bukan berdamai (dengan mereka) karena mereka zalim. Upaya perdamaian disertai dengan kezaliman kelompok tersebut akan menghancurkan hak kelompok yang dizalimi. Banyak kezaliman pihak pendamai (terjadi karena) mendamaikan antara kelompok berkuasa yang zalim dan pihak yang lemah dan terzalimi dengan cara yang disukai oleh pihak yang berkuasa/ kuat yang memiliki pangkat.....".31 
Jadi, gagasan utama perubahan peran penengah (mediator) menjadi advokat adalah untuk menghindari perdamaian yang dilakukan dengan jalan menindas kelompok yang lemah. Itulah bentuk perimbangan kekuatan yang dimainkan oleh pihak ketiga ketika $s$ ly/h/mengalami kegagalan.

Kelima, sly/h\} dalam konteks hubungan kenegaraan antara dasal-Is/am dan daßal-hgrb. $S y / h\}$ semacam itu bisa dilihat prototipnya dalam penyelesaian sengketa pada peristiwa baiat Hudaibiyah. Umat Islam dari Madinah yang berkehendak untuk menjalankan haji ke Makkah dihadang oleh orangorang Quraish. Sempat terjadi aksi lempar batu atau lempar sandal dari kedua belah pihak. Namun Rasulullah mencoba untuk bernegosiasi yang berlanjut dengan sly/h/hantara umat Islam dengan orang-orang Quraish. Hasilnya adalah 1) gencatan senjata selama sepuluh tahun, 2) umat Islam tidak melanjutkan haji tahun ini, tapi boleh berhaji tahun berikutnya dengan pedang tersarungkan, dan 3) jika ada ada orang Islam datang ke Makkah dideportasi ke Madinah, tetapi jika ada orang Makkah yang datang ke Madinah tidak ada deportasi. ${ }^{32}$ S $4 / h$ /ddalam konteks peristiwa baiat Hudaibiyyah ini menunjukkan sebuah proses negosiasi yang menghasilkan kesepakatan bersama antara kedua belah pihak.

Peristiwa tersebut, menurut Ibn Qayyim, mengandung dimensi hukum, yaitu bahwa pimpinan (imam) boleh melakukan inisiasi perdamaian dengan meminta $s l d / h\}$ kepada pihak lain jika ia melihat kemaslahatan bagi umat Islam. Upaya perdamaian itu tidak harus datang dari pihak lawan, melainkan bisa juga datang dari inisiatif pimpinan umat Islam. Perdamaian $(s(l) / h)\}$ yang mengandung unsur kerugian bagi umat Islam boleh dilakukan oleh pimpinan untuk alasan mengambil kemaslahatan yang lebih besar dan mencegah resiko yang berat. ${ }^{33}$
Sylh\} antar umat antar negara tersebut menggunakan mekanisme negosiasi bilateral. Solusi dicari melalui negosiasi antara kedua belah pihak, dengan inisiatif yang muncul dari salah satu pihak. Meskipun sekilas orientasi utamanya adalah conflict settlement, yaitu penghentian konflik dengan kesepakatan yang diterima oleh kedua belah pihak, ${ }^{34}$ namun proses pelaksanaannya bisa dilakukan melalui pendekatan problem solving berdasarkan kepentingan masingmasing pihak. Pemecahan yang lahir dari negosiasi ini bisa merentang dari solusi yang membagi nilai, sebagaimana terjadi dalam negosiasi distributif, maupun solusi yang mampu menciptakan nilai, sebagaimana terjadi dalam negosiasi integratif. $^{35}$ Jadi, sly/h\}dalam hubungan antar negara atau intra negara dicapai melalui negosiasi antara kedua belah pihak, bak dengan kompromi antara dua tuntutan yang berbeda, atau melalui penyelesaian masalah bersama sebagaimana terjadi dalam negosiasi integratif.

Sy/h\}dalam konteks kenegaraan ini adalah bentuk perjanjian antar negara maupun hubungan antar warga negara. $S$ ly/h\}dalam perspektif ini berangkat dari asumsi adanya pertentangan negara kaum muslimin (daß al-/s/am) dengan negara nonmuslim (daßal-hğrb). Agar hubungan konflik itu tidak berlangsung atau kekerasan tidak terjadi, maka ada mekanisme-mekanisme resolusi konflik yang dikenal dalam fikih Islam dengan akad z/mmah, hudnah, dan amax.

a. Akad Z/mmah.

Akad z/mmah terjadi antara pemimpin da»al-/s/am dengan orang atau kelompok nonmuslim yang hidup di bawah kekuasaan Islam. Kelompok yang melakukan akad z/mmah dengan pemimpin Islam itu disebut dengan ahl al- z/mmah atau ahl al-'ahd, sedangkan orangnya disebut dengan $z / m m i$ atau mu'abid. Akad z/mmah terjadi ketika penguasa muslim mengizinkan nonmuslim tinggal di negeri Islam 
dengan tetap memelihara agamanya. Akad z/mmah melahirkan pemeliharaan hak-hak nonmuslim tersebut sebagaimana hak-hak muslim. ${ }^{36}$ Akad z/mmah mengakibatkan lahirnya perlindungan keamanan atas diri, harta, dan keyakinannya oleh pemimpin umat Islam. Sebagai gantinya, z/mmi diwajibkan membayar jizyah (pajak diri) dan melaksanakan beberapa hukum Islam. Kesepakatan $z / m m a h$ bisa terjadi melalui penundukan sukarela untuk menjadi z/mmi, karena sebab mengikuti z/mmi lain, atau karena penaklukan. ${ }^{37}$

b. Mekanisme hudnah (perjanjian gencatan senjata).

Jika pihak lawan ingin melakukan gencatan senjata, umat Islam juga diwajibkan untuk mencari perdamaian, meskipun musuh memiliki rencana tersembunyi. Namun umat Islam tetap harus waspada. Prototipe $s \xi l / h\}$ dalam sejarah Islam adalah peperangan Hudaibiyah yang berakhir dengan perjanjian Hudaibiyah, sebagaimana disebutkan di muka. ${ }^{38}$ Hudnah juga merupakan jalan tengah bagi hubungan antargonistis antara dasal-islam dan das al-hğrb. Al-Shafł'i> menempatkan nonmuslim yang memiliki perjanjian damai dengan umat Islam sebagai kelompok yang hidup dalam daßal-sly/h\} (negeri perdamaian) atau das al-'ahd (negeri berperjanjian), yaitu komunitas nonmuslim yang melakukan perjanjian dengan kaum muslim dengan persyaratan yang disepakati bersama. ${ }^{39}$

c. Mekanisme Akad A max.

Konsep amas mirip dengan pemberian suaka politik atau jaminan keamanan. Pemberian jaminan keamanan itu bisa dilakukan kepada nonmuslim, baik laki-laki maupun perempuan. Menariknya, konsep amas tidak dalam fikih tidak harus diberikan oleh penguasa politik, melainkan bisa juga oleh warga negara, termasuk budak. ${ }^{40}$ Akad amas lahir dari konteks politik yang dibangun

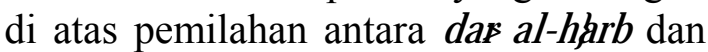
daßal-amas. ${ }^{41}$ Dengan adanya akad amaß nonmuslim bisa memasuki wilayah Islam dengan jaminan keselamatan jiwa dan hartanya, demikian pula sebaliknya. Nonmuslim yang memperoleh jaminan tersebut dikenal dengan sebutan (pencari aman). Legitimasi konsep tersebut, sebagaimana disebutkan oleh Muhammad bin Hasan al-Shaybani> berasal dari praktek Rasulullah, yaitu ketika putrinya Zaynab menjamin amas bagi suaminya A buæal-'A ssjbin al-R abi $>^{42}$

\section{Tahkim}

Jika $s$ ly/h /merupakan payung besar bagi berbagai ragam resolusi konflik dalam hukum Islam, sepatutnya tahkim masuk dalam kerangka $s$ ly/h\} tersebut. Hanya saja, persoalan tahkim perlu dibahas tersendiri mengingat pranata tahkim memiliki sejarah yang khas. Terlebih, dalam kasus perselisihan suamiisteri, Alquran menyebutkan tahkim secara spesifik dalam kasus shiqaq, setelah proses $s$ ly/hkerbukti tidak berhasil. Hal seolah menunjukkan bahwa tahkim memiliki karakteristik khas dibandingkan dengan $s$ ly/hyang lain.

Ciri khas tahkim barangkali terletak kepada sifat memaksa dalam keputusannya, sedangkan sll/h\}yang lain lebih menekankan penyelesaian konflik/sengketa secara konsensual. Meskipun keputusan tahkim bersifat nonbinding (tidak mengikat), namun hasil akhir tahkim itu sendiri tidak didasarkan atas kesepakatan sukarela kedua belah pihak, melainkan oleh pihak ketiga. Oleh karena itu, tahkim seolah menjadi langkah lanjut ketika $s$ ly/h\}gagal tercapai, baik melalui negosiasi maupun melalui mediasi.

Tahkim untuk saat sekarang ini sering diartikan dengan arbitrase, yaitu penyelesaian konflik atau sengketa oleh pihak ketiga. Tahkim dalam masyarakat Arab pra-Islam maupun dalam hukum Islam memang memiliki prinsip yang sama dengan tahkim, namun dengan nuansa yang khas. Tahkim dilakukan oleh ḩÆkam, yang dalam tradisi Arab praIslam, biasa diperankan oleh orang-orang 
yang dikenal kapasitasnya untuk menyelesaikan sengketa. Suku-suku Arab biasanya memiliki ḩॄkam, yaitu orang dipandang memiliki pengetahuan, keadilan, dan kepahaman mengenai tradisi yang hidup dalam sukunya. $H$ gkkam bisa juga berperan melampui batas kesukuan, ketika ia diakui kemampuan dan keadilannya oleh kalangan di luar sukunya. H Hkam tidak memiliki organisasi formal, melainkan diangkat oleh masyarakatnya. ${ }^{43}$

Karir resolusi konflik Nabi Muhammad pada dasarnya dimulai

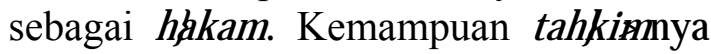
menanjak setelah keberhasilannya mendamaikan persengketaan orang-orang Arab mengenai pemindahan Hajar Aswad, ketika Kakbah direnovasi. Oleh karena itu, Muhammad sebelum diangkat menjadi seorang nabi telah menyandang gelar al-Amin (yang dapat dipercaya), karena kemampuannya mendamaikan perselisihan antarsuku terkait dengan renovasi Ka'bah.

Karir tersebut membuatnya dikenal secara luas, termasuk oleh masyarakat Yathrib (Madinah). Tidak mengherankan ketika terjadi konflik antara suku Aus dan Khazraj (yang keduanya adalah suku-suku Yahudi), kedua belah pihak kemudian sepakat untuk menjadikan Nabi Muhammad sebagai hłkam dan mereka juga masuk Islam. Tidak berhenti di situ, Nabi Muhammad juga meletakkan landasan bagi sistem penyelesaian masalah dalam piagam Madinah, yang di antara muatan intinya, menurut Moussalli, antara lain:

a. Kota (Madinah) terdiri atas berbagai komunitas dari beragama agama

b. Namun, Madinah juga merupakan komunitas politik yang dikepalai oleh Nabi Muhammad

c. Masing-masing komunitas agama mengikuti agamanya sendiri dalam urusan internal

d. Struktur kesukuan tetap dipelihara, khususnya menyangkut masalah ekonomi dan sosial e. Orang Yahudi adalah bagian dari struktur politik dan tunduk kepadanya. Mereka diharus berpartisipasi bersama umat Islam dalam peperangan dan berpartisipasi dalam peace making

f. Dalam hal terjadinya perbedaan pemahaman mengenai piagam Madinah, Allah dan Nabi Muhammad menjadi $h$ Ğkam dan penafsirnya. ${ }^{44}$

Tahkim juga diakui dalam hukum Islam, khususnya dalam persoalan hubungan rumah tangga. Kasus yang secara jelas disarankan dengan mekanisme tahkim adalah kasus syiqa\%, konflik antara suami isteri, sebagaimana disebutkan dalam surat al-Nisas ayat $35 .^{45}$ Istilah syiqac, menurut al-M a ardi> berakar dari dua kemungkinan: 1) masing-masing pihak melakukan sesuatu yang menyusahkan pihak lain dan 2) karena kedua belah pihak mengalami perpecahan akibat permusuhan dan perbedaan. Syiqa ini terjadi akibat nusyuz, baik yang dilakukan oleh pihak suami atau pihak isteri. ${ }^{46}$

Konflik suami-isteri yang diselesaikan dengan menggunakan mekanisme $\left.s, y / h_{2}\right\}$ sebagaimana disebutkan surat al-Nisas ayat 128 - yang telah diulas pada subbab sebelumnya menurut al-M ardi> lebih cocok dipahami dalam konteks konflik yang tidak disertai kekerasan. Apabila konflik suami isteri telah mengakibatkan terjadi kekerasan, maka tahkim inilah mekanisme penyelesaiannya. ${ }^{47}$ Jadi, al$M$ ardi cenderung untuk menegaskan bahwa $s$ l $/ \mathrm{h}$ \} dalam hubungan keluarga diperuntukkan untuk konflik nonkekerasan, sedangkan tahkim untuk konflik yang mengandung kekerasan, yang disebut pula dengan syiqax.

Pendapat al-M ardi> tersebut secara tidak langsung didukung oleh mekanisme penyelesaian nusyuz yang dikemukakan oleh Muhammad 'Ali>alSqbupi> 'Ali> al-S自bupi> berpendapat bahwa ada empat langkah penyelesaian konflik antara suami isteri akibat nusyurz, 
yang keempatnya berdasarkan surat al$\mathrm{Nisa}>$ ayat 34 dan ayat 35 , yaitu:

a. Nasehat, petunjuk, dan hikmah

b. Pisah ranjang dan tidak menggauli isteri

c. Memukul dengan pukulan yang tidak menyakitkan, yaitu dengan kayu siwak

d. Ketika ketiga langkah di atas tidak efektif, diperlukan tahkim. ${ }^{48}$

Jadi, al-Słbupi>secara tidak langsung mengakui bahwa mekanisme tahkim merupakan jalan akhir ketika proses $s|l| h\}$ yang lain gagal.

Proses tahkim dalam kasus semacam itu bisa terjadi dengan tiga cara, yaitu 1) tahkim oleh penguasa tanpa melibatkan hikam, 2) tahkim oleh hakam yang ditunjuk oleh penguasa, dan 3) tahkim oleh hakkam tanpa izin penguasa. Ketika bentuk tersebut, menurut al$M$ ardi> dibolehkan sepanjang hasil akhirnya adalah perdamaian (islath). Perdamaian yang dimaksud di sini adalah perdamaian sehingga kedua belah pihak bersama kembali dan tidak bercerai. Namun apabila keputusan ḩॄkam adalah cerai, yang didasarkan atas izin hakim, terjadi dua versi pendapat Ahmad bin Idris al-Syaff'i>Satu versi pendapat alSyafi'i> menyatakan bahwa keputusan hłkam untuk menceraikan suami-isteri harus didasarkan dan berlaku sah apabila ada pemberian wewenang (tauki suami dan isteri. Satu versi al-Syafi'i> yang lain membolehkan ḩ\$kam memutuskan hubungan kedua belah pihak, tanpa adanya pemberian wewenang oleh suami dan isteri, dengan izin penguasa. ${ }^{49}$

Jadi, pada prinsipnya tahkin digunakan dalam sengketa atau konflik politik dan konflik yang terkait dengan muamalah dan sebagian masalah keluarga, seperti shiqa di atas. Hanya saja, menurut Rashid, sebagaimana dikutip oleh MD Zahidul Islam, arbitrasi tidak bisa dilakukan dalam konteks hudue. tidak hanya hudud, persoalan li'aA, wakaf, nasab, fasakh nikah, pembebasan budak, dan kedewasaan tidak bisa diputuskan oleh ḩ̧kam, melainkan diputuskan oleh hakim. ${ }^{50}$

Oleh karena itu, di kalangan Mazhab Hanafi, tahkim dipandang terkait dengan kontrak. Arbitrator ( hq kam) bertindak lebih sebagai agen yang mewakili para pihak yang bersengketa. Meskipun keputusan ḩ\$kam tidak kuat ikatannya, namun memiliki kekuatan yang memaksa para pihak untuk mentaatinya. Sementara itu, mazhab Maliki hgkam dipilih dari salah satu pihak yang bersengketa dan tidak dapat dicabut mandatnya di tengah proses perkara. Namun menurut al-Syafi' $i>$

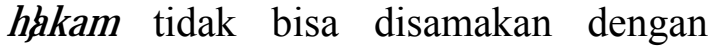
hakim dan ia dapat digantikan sebelum mengeluarkan keputusan. Sebaliknya, kalangan Hanbali berpendapat bahwa takhim memiliki dampak sebagaimana proses pengadilan dan hłkam sama dengan hakim yang keputusannya mengikat para pihak yang menunjuknya. ${ }^{5}$

Kesimpulan yang bisa ditarik bahwa tahkim sebenarnya adalah bentuk upaya mencari perdamaian. Hanya saja ada perbedaan khas antara tahkim dan sly/h.\} Pertama, sly/h\}lebih menunjukkan kesepakatan yang bersifat sukarela, sedangkan dalam tahkim keputusan hłkam lebih bersifat memaksa. Kedua, Syl/hlebih menekankan kesepakatan yang dibuat oleh kedua belah pihak, meskipun difasilitasi oleh pihak ketiga. Sementara itu, keputusan dalam tahkim justru lahir dari pihak ketiga. Ketiga, sly/h/merupakan pendekatan yang merangkum berbagai model resolusi konflik, mulai konflik personal, konflik komunal, konflik intrastate, sampai kepada konflik antarnegara dan kewarganegaraan.

Persamaan yang jelas antara $s, \boldsymbol{l} / \mathrm{h}\}$ dengan tahkim adalah bahwa keduanya berlaku dalam kasus-kasus yang termasuk dalam kategori hak-hak manusia (haqq al-adłamil, tidak dalam kasus-kasus yang termasuk hak Allah. Hak-hak Allah, menurut Ibn Qayyim, adalah semisal huduw, kaffarat, dan zakat. Sylh\}dalam 
hak-hak Allah menurutnya hanya satu, yaitu dengan menjalankannya. Sementara itu, kasus-kasus yang terkait dengan hakhak manusia lah yang terbuka untuk sly/h. $\xi^{2}$

\section{Resolusi Konflik Alternatif Hukum Islam dan Resolusi Konflik Alternatif Modern}

Berdasarkan uraian sebelumnya dapat disimpulkan bahwa ada dua model resolusi konflik alternatif utama dalam hukum Islam, yaitu sly/h\} dan tahkim. Sebenarnya ada yang memetakan lebih banyak lagi model resolusi konflik dalam hukum Islam. Penulis Malaysia, Md. Zahidul Islam, misalnya, memetakan ada enam model resolusi konfik dalam hukum Islam:

1. Sly/h.\}S mengandung dimensi negosiasi, mediasi, konsiliasi, atau tindakan kompromi.

2. tahkim (arbitration);

3. med-arb (a combination of sly/h\}and tahkim);

4. muhţasib (ombudsman);

5. informal justice by the wali almazalim or chancellor; and

6. fatwa of muftis (expert determination

Namun sly/h\}dan tahkim lebih merepresentasikan ADR. Muhtasib dan wali al-mazalim dalam hukum Islam lebih merupakan fungsi penjagaan moral umum dan moral aparatus, dibandingkan sebagai mekanisme resolusi konflik. Adapun fatwa lebih merupakan pernyataan normatif oleh ahli hukum Islam dan lebih banyak mendukung institusi peradilan dibandingkan dengan ADR. Oleh karena itu, resolusi konflik dalam artikel ini dibatasi hanya kepada sly/hllan tahkim.

Untuk memahami posisi sly/h\}dan tahkim dalam konteks resolusi konflik modern, terlebih dahulu perlu diperjelas peta resolusi konflik yang mapan saat ini. Dalam tradisi resolusi konflik modern dikenal beberapa model resolusi konflik, seperti dialog informal, negosiasi, mediasi, keputusan administratfi, arbitrase, litigasi, hingga legislasi dan dengan berbagai variasi dan kombinasi dari berbagai model di atas. Model-model tersebut ada yang dikategorikan sebagai model resolusi konflik/sengketa alternatif (alternative dispute resolution) dan ada pula yang dipandang sebagai model dominan, seperti litigasi dan legislasi. Christopher W. Moore, seorang pakar mediasi, mencoba untuk memetakan model-model resolusi konflik yang berkembang saat ini dan menempatkan model-model tersebut dalam sebuah dalam sebuah kontinum sebagaimana berikut:

Bagan 3

Kontinum Resolusi Konflik ${ }^{53}$

\begin{tabular}{|c|c|c|c|c|c|c|c|c|c|}
\hline \multicolumn{4}{|c|}{ Keputusan mandiri oleh para pihak } & \multicolumn{2}{|c|}{$\begin{array}{l}\text { Keputusan oleh } \\
\text { pihak ketiga non } \\
\text { penguasa }\end{array}$} & \multicolumn{2}{|c|}{$\begin{array}{l}\text { Keputusan oleh } \\
\text { pihak ketiga } \\
\text { pemegang otoritas }\end{array}$} & \multicolumn{2}{|c|}{$\begin{array}{c}\text { Keputusan yang } \\
\text { dilaksanakan di luar } \\
\text { hukum }\end{array}$} \\
\hline $\begin{array}{l}\text { Menghindar } \\
\text { Konflik }\end{array}$ & $\begin{array}{l}\text { Diskusi } \\
\text { informal }\end{array}$ & Negosiasi & Mediasi & $\begin{array}{c}\text { Keputusan } \\
\text { administratif }\end{array}$ & Arbitrase & $\begin{array}{l}\text { Keputusan } \\
\text { pengadilan }\end{array}$ & $\begin{array}{l}\text { Keputusan } \\
\text { legislatif }\end{array}$ & $\begin{array}{l}\text { Tindakan } \\
\text { langsung } \\
\text { tanpa } \\
\text { kekerasan }\end{array}$ & $\begin{array}{c}\text { Kekerasan } \\
\text { (perang) }\end{array}$ \\
\hline
\end{tabular}


Berdasarkan gambar di atas tampak bahwa model resolusi konflik yang dipaparkan oleh Moore membentang dari penghindaran konflik (conflict avoidance) sampai kepada kekerasan atau perang. Resolusi konflik juga bisa menghasilkan kesepakatan yang dibuat oleh para pihak maupun oleh pihak ketiga, baik penguasa atau non penguasan.

Mengindari konflik, diskusi informal, negosiasi, mediasi menjadi satu kategori resolusi konflik berdasarkan oleh siapa keputusan dibuat, yaitu oleh para pihak sendiri. Namun keempatnya memiliki perbedaan mendasar:

1. Menghindar konflik pemecahan masalahnya lahir dari para pihak dengan cara tidak menyelesaikan masalah, melainkan menghindarinya

2. Diskusi informal telah melibatkan komunikasi antara kedua belah pihak, namun bersifat longgar dan tidak terlalui berorientasi kepada pencapaian kesepakatan yang terukur dan jelas

3. Negosiasi merupakan perkembangan lebih lanjut dari diskusi informal dalam hal oientasinya kepada kesepakatan. Hal itu tampak dari definisi mediasi yang dikemukakan oleh David Spencer dan Michael Brogan, yaitu: "proses dimana dua pihak atau lebih bekerja bersama (mengatasi) konflik mereka dengan pandangan untuk sampai kepada kesepakatan terhadap konflik atau sengketa mereka." 54

4. Mediasi adalah negosiasi yang difasilitasi oleh pihak ketiga. Meskipun keputusan dibuat oleh para pihak, namun ada pihak ketiga yang memfasilitasi komunikasi dan negosiasi. Mediator, sebagai pihak ketiga, bersifat netral. Ada yang membedakan mediasi dan konsiliasi dimana yang pertama kesepakatan dibuat dan diusulkan oleh para pihak, sedangkan yang kedua kesepakatan diajukan oleh mediator kepada para pihak. ${ }^{55}$ Konsiliasi semacam itu mirip mediasi evaluatif, yaitu mediasi yang berpijak terhadap aturan hukum, atau mediasi settlement, yang berorientasi kepada penyelesaian sengketa atau konflik secara kompromistis.

5. Arbitrase menandai peran lebih besar pihak ketiga dalam pembuatan kesepakatan. Pihak ketiga ditunjuk oleh para pihak untuk menjadi pemutus sengketa. Arbitrase memiliki memiliki persamaan dengan pengadilan, namun perbedaannya terletak kepada sifat mengikat dari keputusan yang dibuat oleh arbitrator dengan yang dibuat oleh hakim. Dalam sejarah Islam sendiri, fungsi yudisial sebenarnya adalah pengembangan dari arbitrase (tahkim).

Kelima model resolusi konflik tersebut mewakili alternative dispute resolution (ADR) modern. Sementara itu, resolusi konflik oleh hakim dan oleh anggota legislatif bersama pemerintah melalui legislasi bisa dipandang sebagai arus dominan resolusi konflik. Jadi, pada dasarnya resolusi konflik modern membentang mulai dari dialog sampai kepada arbitrase.

Sementara itu, resolusi konflik dalam hukum Islam, khususnya yang alternatif, diwakili oleh sly/h\}dan tahkim. Kedua resolusi konflik tersebut bisa dikatakan sama karena term sly/h\} mencakup berbagai ragam model resolusi konflik, namun dalam hukum Islam tahkim bisa dibedakan dengan sly/h/lalam hal-hal berikut: 
Tabel 1

Perbedaan Sylhklan Tahkim

\begin{tabular}{|l|l|l|}
\hline Aspek & Słl/h\} & Tahkim \\
\hline Orientasi hubungan & Berorientasi hubungan & Tidak berorientasi hubungan \\
\hline Asas keadilan & Restoratif & Distributif/ retributif \\
\hline $\begin{array}{l}\text { Pihak yang mengambil } \\
\text { keputusan }\end{array}$ & $\begin{array}{l}\text { Pihak satu dengan pihak lain } \\
\text { (with other) }\end{array}$ & Oleh pihak ketiga (by other) \\
\hline
\end{tabular}

Dari tabel di atas tampak bahwa sly/h\} secara umum lebih menekankanaspek relaasi, keadilan restoratif, dan penyelesaian bersama antara pihak yang bersengketa atau berkonflik (penyelesaianwith the other). $S y / h$ \}secara umum mengandung dimensi pemberdayaan diri oleh para pihak melalui upaya dialog, negosiasi, dan rekonsiliasi sehingga dimensi hubungan dapat mengalami proses pemulihan. Orientasi utama $s$ l $/ \mathrm{h} / \mathrm{h}$ \}adalah peniadaan konflik melalui kesepakatan yang melibatkan para pihak yang bersengketa.

Namun demikian, ada beberapa problem model s $s$ l/h.\} Pertama, sly/h\} memberi penekanan yang besar kepada hubungan dan kepercayaan sehingga membuat keputusan yang dihasilkannya kurang mengikat. Kedua, karena menekankan penyelesaian konflik with other, sly/h\} relatif kurang mengikat keputusannya dan bisa terganggu ketika para pihak menarik diri dari keputusan. Meskipun untuk saat sekarang, hasil keputusan $s l l / h$ \}bisa saja diratifikasi. ${ }^{56}$ Ketiga, sly/h\} rawan menimbulkan pemaksaan kehendak pihak yang kuat kepada pihak yang lemah, ketika terjadi kesenjangan besar kekuatan atau kekuasaan antara kedua belah pihak.

Model-model resolusi konflik dalam $s l y / h\}$ sangat kaya dan mencakup level konflik interpersonal hingga antarnegara. Jika diletakkan dalam sebuah tabel, maka resolusi konflik alternatif dalam sly/h\} memiliki mekanisme dan persamaan term dengan resolusi konflik alternatif modern sebagai berikut:

Tabel 2

Mekanisme dan Persamaan Sly/hłldengan Resolusi Konflik Alternatif Modern

\begin{tabular}{|c|c|c|c|c|c|}
\hline Model Slyl/h\} & $\begin{array}{c}\text { sly/hklalam } \\
\text { konflik } \\
\text { interpersonal } \\
\text { (konflik keluarga) }\end{array}$ & $\begin{array}{l}\text { Sylhłdalam } \\
\text { kasus perdata } \\
\text { (mengenai } \\
\text { harta) }\end{array}$ & $\begin{array}{c}\text { sly/hłdalam kasus } \\
\text { pembunuhan }\end{array}$ & $\begin{array}{c}\text { Syl/hłdalam kasus } \\
\text { konflik komunal }\end{array}$ & $\begin{array}{c}\text { Sylhjdakan konteks } \\
\text { hubungan konflik } \\
\text { antarnegara }\end{array}$ \\
\hline Mekanisme & $\begin{array}{c}\text { Perdamaian } \\
\text { dengan jalan } \\
\text { kompromi antara } \\
\text { suami dan isteri }\end{array}$ & $\begin{array}{l}\text { Perdamaian } \\
\text { dengan jalan } \\
\text { kompromi }\end{array}$ & \begin{tabular}{|c|} 
Perdamaian \\
dengan \\
pemaafan oleh \\
keluarga korban, \\
baik dengan atau \\
tidak disertai \\
kompensasi \\
(diyat)
\end{tabular} & $\begin{array}{l}\text { Perdamaian dengan } \\
\text { jalan penghentian } \\
\text { kekerasan, bisa pula } \\
\text { sampai kepada } \\
\text { pembuatan } \\
\text { kesepakatan bersama }\end{array}$ & $\begin{array}{c}\text { Perdamaian dengan akad } \\
\text { pemberian hak } \\
\text { kewarganegaraan } \\
\text { (dhimmah) gencatan } \\
\text { senjata (hudnah), } \\
\text { pemberian suaka (aman) }\end{array}$ \\
\hline $\begin{array}{l}\text { Model } \\
\text { resolusi } \\
\text { konflik }\end{array}$ & \begin{tabular}{|c|} 
Mengandung \\
dimensi negosiasi \\
distributif hard \\
atau soft
\end{tabular} & $\begin{array}{l}\text { Mengandung } \\
\text { dimensi } \\
\text { negosiasi } \\
\text { distributif hard } \\
\text { atau soft }\end{array}$ & \begin{tabular}{|c|} 
Mengandung \\
dimensi \\
rekonsiliasi atau \\
restorative \\
justice
\end{tabular} & $\begin{array}{c}\text { Mengandung dimensi } \\
\text { negosiasiatau dialog. } \\
\text { Bisa juga dipandang } \\
\text { sebagai bentuk peace } \\
\text { making }\end{array}$ & $\begin{array}{l}\text { Mengandung dimensi } \\
\text { perdamaian melalui } \\
\text { mekanisme politik }\end{array}$ \\
\hline
\end{tabular}


Tahkim di sisi lain sangat menekankan otoritas pihak ketiga dan perannya untuk mengambil keputusan. Dalam konteks tersebut, tahkim menyerupai arbitrase. Hanya saja, dalam tahkim konflik keluarga - antara suami dan isteri - pihak ketiga bukanlah satu pihak yang dipandang otoritatif oleh kedua pihak yang bertikai, melainkan lebih merupakan pihak yang mewakili masing-masing pihak yang bersengketa untuk bernegosiasi. Hasil negosiasi pihak ketiga tersebut boleh jadi mengikat, utamanya ketika pihak ketiga yang ditunjuk oleh masing-masing pihak tersebut dikukuhkan oleh hakim. Akan tetapi ketika pihak ketiga tersebut tidak dikukuhkan oleh hakim, keputusannya khususnya keputusan untuk menceraikan suami dan isteri - masih harus disetujuan oleh kedua belah pihak, jadi, tahkim dalam konteks hukum Islam menempati posisi antara, yaitu antara mediasi dan arbitrase (med-arb).

\section{Kesimpulan}

Dari uraian di atas, dapat disimpulkan bahwa resolusi konflik alternatif dalam hukum Islam utamanya terwujud dalam sly/h\}dan tahkim. Sylh\} menjadi payung dari berbagai resolusi konflik alternatif, baik konflik atau sengketa interpersonal, komunal, dalam negeri, hingga antarnegara. keberadaan sly/hlitu kemudian ditopang oleh tahkim yang bertindak sebagai mekanisme lanjutan dari $s|l| / h\}$ ketika $s|l| h\}$ gagal mencapai kesepakatan.

Sly/h)lan tahkim memiliki beberapa model yang mirip dalam resolusi konflik alternatif modern, yaitu negosiasi, rekonsiliasi, dan pemberian jaminan hak (dalam $s(y / h)\}$ dan mediasi yang dikombinasikan dengan arbitrase (dalam tahkim). Meskipun ada padanan dalam resolusi konflik alternatif modern, model resolusi konflik alternatif dalam hukum Islam memiliki ciri-ciri khas, yaitu:

1. Resolusi konflik alternatif dalam hukum Islam berlandaskan kepada idiom-idiom keagamaan dan memiliki basis epistemologis kepada wahyu dan Rasul. $^{57}$

2. Resolusi konflik alternatif dalam hukum Islam lebih menekankan penyelesaian konflik bersama (with other) sehingga mekanisme negosiasi dan pemberian jaminan keamanan atas hak-hak menjadi pilihan dalam sly/h\} dan kombinasi mediasi dan arbitrase menjadi pilihan dalam tahkim.

3. Resolusi konflik dalam Islam hanya berlaku untuk perkara-perkara yang menjadi hak manusia dan tidak masuk wilayah hak-hak Tuhan, yaitu persoalan ritual dan hukum-hukum yang telah ditentukan kadarnya (huduef). Pemilahan antara hak manusia dan hak Tuhan tersebut tidak identik dengan pemilahan antara perdata dan pidana dalam hukum Barat.

Terlepas dari perbedaan antara resolusi konflik alternatif dalam hukum Islam dan model resolusi konflik modern, namun keduanya memiliki banyak persamaan. Persamaan tersebut terletak kepada prosedur yang longgar yang dimiliki oleh baik resolusi konflik alternatif modern maupun hukum Islam dan dimungkinkannya perberdayaan kepada para pihak untuk mencari solusi bersama. Kedua resolusi konflik alternatif tersebut menyediakan jalan pilihan ketika jalan utama (litigasi dan legislasi) mengandung kelemahan dan inefisiensi dalam menyikapi sebuah kasus konflik. 


\section{Catatan Akhir:}

${ }^{1}$ Iistilah syariat Islam dalam tulisan ini dipergunakan secara saling menggantikan dengan hukum Islam dan memiliki hubungan erat dengan istilah fikih. Dalam tulisan ini syariat Islam dipahami sebagai hukum yang digali dari sumbersumber syar'i>baik yang bersifat $z$ ann maupun qat\}i>

${ }^{2}$ Kecurigaan terhadap dimensi kekerasan dalam hukum Islam tersebut antara lain dikemukakan oleh para ahli, seperti Abdullehi Ahmed an-Naim. An-Naim menyoroti muatan diskriminatif syariat Islam, khususnya dalam tiga persoalan utama, 1) hubungan antarumat beragama, 2) perempuan, dan 3) perbudakan. Lihat uraiannya dalam Abdullehi Ahmed AnNaim. Toward an Islamic Reformation: Civil Liberties, Human Right, and International Law (New York: Syracuse University Press, 1996), hlm. 170-173.

${ }^{3}$ Lihat misalnya dalam Taqi $ə a l-D i p$ A bu> Bakr al-Husayni>K ifapah al-A khyar fi $H$ \&l/l Alfaz\} A bisyujas(Surabaya: al-Hidaæah, t.t.)

${ }^{4}$ Demikian Majid Khadduri memberikan sebutan bagi kitab siyar sebagai buku mengenai hukum internasional versi hukum Islam. The Islamic Law of Nations: Shyabani Siyar (Baltimore: John Hopkins Press, 1966).

${ }^{5}$ Lihat dalam Penjelasan mengenai mediasi settlement, evaluatif, fasilitatif, dan transformatif lihat dalam Lihat dalam David Spencer dan Michael Brogan, Mediation, Law and Practice (Cambridge: Cambridge University Press, 2006), hlm. 100-109. Mediasi naratif dapat dibaca penjelasannya dalam John Winslade dan Gerarld Monk, Narrative Mediation: A New Approach to Conflict Resolution (San Fransisco: Jossey-Bass Publisher, 2000). Adapun mediasi unity-based dapat dibaca penjelasannya dalam Hossein B. Danesh dan Roshan Danesh, "A Consultative Conflict-Resolution Model: Beyond Alternative Dispute Resolution," Internation Journal of Peace Studies, Vo. 7. Number 1 Autumn/Winter 2001.

${ }^{6}$ Peace making adalah intervensi konflik yang ditujukan untuk mengakhiri kekerasan dan membawa kepada kesepakatan dengan menggunakan sarana diplomasi, politik, maupun militer. Peace keeping adalah monitoring dan penguatan kesepakatan, bila perlu dengan menggunakan kekuatan. Hal itu mencakup pula proses pengecekan apakah kesepakatan dipatuhi dan supervisi kegiatan untuk membangun saling kepercayaan. Peace building adalah programprogram yang ditujukan untuk mengatasi akar konflik dan kemarahan serta untuk mempromosikan perdamaian jangka panjang. Lihat dalam Simon Fisher et.al. Working with
Conflict: Skills and Strategis for Action (London, New York: Zed Book Ltd. 2000), hlm. 14.

${ }^{7}$ Istilah perdamaian dalam artikel ini digunakan dalam pengertian luasnya, yaitu negative peace dan positive peace. Johan Galtung - seorang pakar perdamaian dari Norwegia -. membagi perdamaian menjadi dua, yaitu negative peace dan positive peace. Negative peace adalah kondisi damai karena tidak ada perang atau konflik. Sementara itu, positive peace adalah perdamaian dalam pengertian yang lebih luas, yaitu struktur dan kultur yang mendukung terciptanya perdamaian abadi. Namun demikian, resolusi konflik sendiri sebenarnya lebih menekankan aspek negatif peace, namun sebagian tetap berorientasi kepada hubungan jangka panjang

${ }^{8}$ Tentang piagam Madinah dan peran Nabi Muhammad akan lebih lanjut diuraikan pada bahasan Model Resolusi Konflik .

${ }^{9}$ Otoritas epistemis adalah tokoh yang memiliki kapasitas untuk mengetahui, menjabarkan, menafsirkan, dan menerapkan hukum. Otoritas tersebut menggabungkan di dalamnya kekuasaan agama, moral, sosial, dan hukum sekaligus. Lihat Wael B. Hallaq. "Juristic Authority Vs State Power: The Legal Crises of Modern Islam." Jurnal of Law and Religion. Vol. 19. No. 2. 2003-2004. hlm. 243-244

${ }^{10} \mathrm{~T}$ abrapi $>$ meriwayatkan bahwa spesialis pengadilan (ashab al-gadłs) pada masa Nabi Muhammad ada enam, yaitu 'Umar, Ali, 'Abdullah ibn Mas'ud, Ubay ibn Ka'b, Zayd ibn Sabit, dan Abu> Musa> al-Asy'ari> Nabi Muhammad juga diriwayatkan mengirimkan Ali

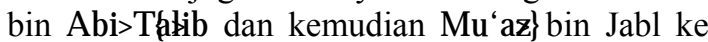
Yaman, 'Utab ibn Asiф ke Makkah. Nabi Muhammad terkadang meminta sahabatnya untuk menyesaikan kasus tertentu yang datang beliau, seperti sahabat 'Uqbah ibn A mir al-J uhni>dan $M$ a' qil ibn $Y$ asas al-M uzani $>$ Lihat $M$ uhłammad

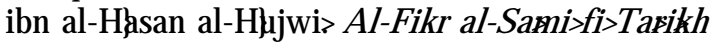
al-Figh al-Islami> (B eirut: Das al-Kutub al'Ilmiyyah, 1995), I: 228-230.

${ }^{11}$ Lihat Taqi> al-Dip Abu> Bakr alHusayni> Kifasah, I: 271. Ibnu Qudamah mendefinisikan $s$ l $/$ /h\} sebagai "upaya mencari kesepakatan untuk is/ak di antara dua pihak yang berbeda (معاقدة يتوصل بها الى الاصلاح بين المختلفين)". Lihat Ibn Qudamah, al-Mughni, (Beirut: DaßalKutub al-'Ilmiyyah, t.t.), V: 2. Pada dasarnya kitab-kitab fikih sepakat bahwa sly/h\} adalah sebentuk akad untuk menyelesaikan sengketa.

${ }^{12}$ Ibn Qudamah, al-Mughni,V: 2

${ }^{13}$ Syiqa adalah perbedaan dan permusuhan yang membuat kedua belah pihakisteri dan isteri- berada dalam posisi berseberangan akibat permusuhan antara 
keduanya. Lihat al- Muhammad 'Ali >al-Słbupi> TafsisA Ibn 'A bbu\&, 2004), I: 332.

${ }^{14}$ Lihat Syams al-Dip Muhammad bin 'A bbasal-Ramli>Nihapah al-M uhtajila Syarh zalMinhaj (Beirut: Das al-Kutub al-'Ilmiyyah, 1993), III: 382.

${ }^{15}$ Sahipup, al-M udawwanah al-Kubra> (B eirut: Daßal-Kutub al-'Ilmiyyah, 1994)III: 382387.

${ }^{16}$ W ahbah Zuhgyli>al-Figh al-Islami> $w a$ A dillatuh (Damaskus: Das al-Fikr al-M u'asijr, 1997), IV: 4332.

${ }^{17}$ Menurut levelnya konflik terbagi menjadi konflik intrapersonal, konflik interpersonal, konflik komunal atau antarkelompok, konflik dalam negara (interstate), dan konflik antarnegara.

${ }^{18}$ Q.S. al-N isał $\Varangle$ 4): 128 menyebutkan:

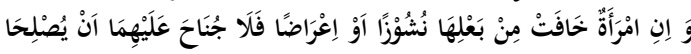

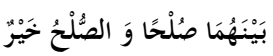

Jika seorang wanita khawatir akan nusy (»atau sikap tidak acuh dari suaminya, maka tidak mengapa bagi keduanya mengadakan perdamaian yang sebenar-benarnya. Perdamaian itu lebih baik.

${ }^{19} \mathrm{Al}$-Qur'an surat al-Nisabayat 34:

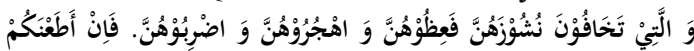

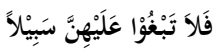

Wanita-wanita yang kamu khawatiri nusyuz nya, maka nasehatilah mereka, dan pisahkan diri dari tempat tidur mereka, dan pukullah mereka, kemudian jika mereka mentaatimu, maka janganlah kamu mencari-cari jalan untuk menyusahkannya.

${ }^{20}$ Sayyid Sabiq, Fiqh al-Sunnah (B eirut: Daßal-Fikr, 1983), II: 263.

${ }^{21}$ Saudah binti Zam'ah merasa dirinya tua dan takut Nabi Muhammad menceraikannya. Lalu ia mengambil keputusan untuk memberikan giliran harinya kepada 'A syah. Namun, ia masih memperoleh hak nafkah dan sandang. Sayyid Sabiq mengutip hadis 'A $A$ syah yang diriwayatkan oleh A bu» $\gg$ awud.

${ }^{22}$ Ibn Qayyim al-Jawziyyah, Zađ alMa'ad fi Hadti>K hayr al-'Ibad (Beirut: Daß alFikr. 1995), III: 85.

${ }^{23}$ H.R. Riwayat Ibnu Hibban

24 Al-Zuhłyli> al-Fiqh al-Islami> IV:

4333.

${ }^{25}$ Syams al-Din Muhammad bin 'A bbas al-Ramli, Nihaæah, IV: 384. 4334-dst.

26 Al-Zuhłyli> al-Fiqh al-Is/ami> IV:

${ }^{27}$ Ibid., IV: 4353.

${ }^{28}$ Bagan tersebut diambil dari subbab tentang rekonsiliasi dalam David Bloomfield,
Teresa Barnes and Luc Huyse (eds.) "Reconciliation after Violent Conflict", dalam http://www.idea.int. Diakses tanggal 23 Juli 2009.

${ }^{29} \mathrm{~A}$ bu>al-H dasan 'A li >al-M awardi, al$H$ dmisal-Kabis (Syarh\} M ukhtasdr al-M uzannip (Beirut: Daß al-Kutub al-'Ilmiyyah, 1999), XII: 200-201.

${ }^{30}$ Bunyi ayat tersebut:

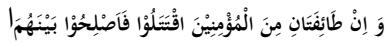

${ }^{31}$ Ibn Qayyim al-Jawziyyah, I'lam alM uwaqqi'in' 'an Rabb al-'A kamia (Beirut: DaßalKutub al-'Ilmiyyah, 1996), I: 85.

${ }^{32}$ Al-Jawziyyah, Za® al-M a'ad, III: 252261.

${ }^{33}$ Ibid., III: 264 dan 265.

${ }^{34}$ Lihat Fisher et.al. Working with Conflict, hlm. 7

${ }^{35}$ Negosiasi distributif adalah negosiasi yang bertujuan untuk membagi nilai atau untuk memenangkan sebuah nilai. Negosiasi distributif banyak dilakukan, seperti di pasar, negosiasi untuk mendapatkan proyek dan sebagainya. Prinsip dasar negosiasi distributif adalah untuk memperoleh hasil maksimal dengan pengeluaran atau konsensi yang yang diberikan oleh pihak lain sehingga negosiasi distributif disebut juga dengan negosiasi kompetitif. Uraian mengenai strategi negosiasi distributif dapat dibaca dalam Gary Goodpaster, A Guide to Negotiation and Mediation (New York: Transnational Publisher, Inc. 1997). Sebaliknya, negosiasi integratif adalah negosiasi yang berorientasi kepada penyelesaian masalah (problem solving) secara bersama oleh kedua belah pihak sehingga masing-masing bisa mendapatkan secara maksimal apa yang dibutuhkannya. Negosasi integratif berusaha menciptakan nilai baru sehingga menuntut kreativitas dalam mencari solusi. Prinsip dan strategi negosiasi integratif dapat dibaca dalam Roger Fisher dan William Ury, Getting to Yes: Negotiating an Agreement without Giving in (New York: Penguins, 1987). berlaku:

${ }^{36}$ Oleh karena itu, ada kaidah yang

$$
\text { أَنَّ لَهُمْ مَا لَنَا وَ عَلَيْهِمُ مَا عَلَيْنَاً }
$$

Mereka (ahl al-ziłmmah) miliki (hak) sama dengan hak kita (umat Islam) miliki dan mereka menanggung apa yang kita tanggung. Lihat Sabiq, Fiqh al-Sunnah, III: 64-65.

${ }^{37}$ Lihat Wizarah al-A wqas wa al-Syu' up al-Islamiyyah, al-Mawsusah al-Fiqhifyyah (K uwait: Z abal-Salasil, 1992), VII: 120-121.

${ }^{38}$ Lihat Sabiq, Fiqh al-Sunnah, III: 62-

63.

${ }^{39}$ Lihat pengantar dalam Khadduri, The Islamic Law, hlm. 12.

${ }^{40}$ Lihat Sabiq, Fiqh al-Sunnah, III: 94. 
${ }^{41} \mathrm{~A}$ I-Syafi'i>memberikan satu spektrum ketiga yang berada di antara kedua daßtersebut, yaitu da»al-sly/h\}atau daßal-'ahd, yaitu komunitas nonmuslim yang melakukan perjanjian dengan kaum muslim dengan persyaratan yang disepakati bersama. Lihat pengantar dalam Majid Khadduri. The Islamic Law, hlm. 12.

${ }^{42}$ Lihat Ibid., hlm. 158-159.

${ }^{43}$ Ahmad S. Moussalli. "An Islamic Model for Political Conflict Resolution: Takim (Arbitration)" dalam Abdul Aziz Said, Nathan C. Funk, dan Ayse S. Kadayifci, Peace and Conflict Resolution in Islam (Lanham, New York, Oxford: University Press of America. Inc., 2001), hlm. 145.

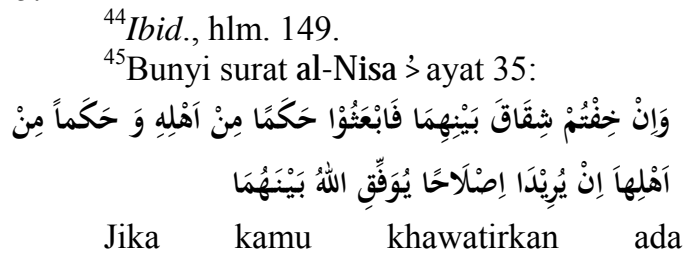
persengkataan antara keduanya, maka kirimlah seorang hłkam dari keluarga laki-laki dan seorang hłkam dari keluarga perempuan. Jika kedua hłkam itu bermaksud mengadakan perbaikan, niscaya Allah memberikan taufik kepada suamiisteri itu.

${ }^{46} \mathrm{~A}$ I-M awardi, A /-H dorizl-Kabis, IX :

601.

335.

${ }^{47}$ Ibid., hlm. 601-602.

${ }^{48} \mathrm{~A}$ I-Słbupi>T afsir $A$ pabal-A hkam, I: 602-603.

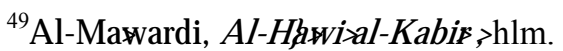

${ }^{50} \mathrm{Md}$. Zahidul Islam. "Provision of Alternative Dispute Resolution Process in Islam." IOSR Journal of Business and Management (IOSR-JBM). Volume 6, Issue 3 (November December. 2012. h. 33. hlm. 34

${ }^{51}$ Sebagaimana dijelaskan dalam Ibid.

${ }^{52}$ Ibnu Qayyim al-Jauziyyah, I'/am alM uwaqqi'ia, hlm. 85.

${ }^{53}$ Christopher W. Moore, The Mediation Process: Practical Strategies for Resolving Conflict (San Fransisco: Jossey-Bass, 2003), hlm. 7

9.

${ }^{54}$ Spencer dan Brogan, Mediation, hlm.

${ }^{55}$ Memang terdapat berbagai perbedaan mengenai hubungan antara mediasi dan konsiliasi. Ada sebagian pihak yang menyamakan mediasi dan konsiliasi. Hal itu didasarkan kenyataan bahwa prosedur konsiliasi dan mediasi sama-sama longgar dan pihak ketiga tidak bisa mengeluarkan keputusan yang mengikat. Ada pula yang memandang bahwa konsiliasi menempati posisi "antara", yaitu antara mediasi dan arbitrase. Dalam konsiliasi, peran pihak ketiga lebih besar dalam menentukan hasil kesepakatan. Konsiliasi berlangsung di lembaga publik dengan pertimbangan hukum lebih kental. Lihat dalam Laurence Boulle dan Teh Hwe Hwe, Mediation: Principles, Process, Practice (Singapore: Butterworths Asia. 2000), hlm. 67-68.

${ }^{56}$ Ratifikasi adalah pengesahan hasil kesepakatan perdamaian. Ratifikasi dilakukan dengan menjadikan hasil kesepakatan agar memiliki kekuatan hukum.

${ }^{57}$ Pendapat semacam ini juga dikemukakan oleh George E. Irani dan Nathan C. Funk dalam "Rituals of Reconciliation: ArabIslamic Perspectives," dalam Said, Funk, dan Kadayifci, Peace and Conflict, hlm. 181.

\section{DAFTAR PUSTAKA}

Annaem, Abdullehi Ahmed. Toward an Islamic Reformation: Civil Liberties, Human Right, and International Law. New York: Syracuse University Press, 1996.

Bloomfield, David, Teresa Barnes and Luc Huyse (eds.) Reconciliation after Violent Conflict, dalam http://www.idea.int, di akses 23 Juli 2009

Boulle, Laurence dan Teh Hwe Hwe. Mediation: Principles, Process, Practice/. Singapore,Butterworths Asia, 2000.

Danesh, Hossein B. dan Roshan Danesh. "A Consultative ConflictResolution Model: Beyond Alternative Dispute Resolution." Internation Journal of Peace Studies, Vo. 7. Number 1 Autumn/Winter 2001.

Fisher, Roger dan William Ury. Getting to Yes: Negotiating an Agreement without Giving in. New York: Penguins, 1987.

Fisher, Simon etc. Working with Conflict: Skills and Strategis for Action. London, New York: Zed Book Ltd, 2000.

Goodpaster, Gary. A Guide to Negotiation and Mediation. New York: Transnational Publisher, Inc., 1997. 
Hallaq, Wael B. "Juristic Authority Vs State Power: The Legal Crises of Modern Islam." Jurnal of Law and Religion. Vol. 19, No. 2, 20032004.

Al-H \&্jwi, M uhąmmad ibn al-H đ̧san $>A /-$ Fikr al-Sami>fi>Tarikh al-Fiqh alIslamil> Beirut: Das al-Kutub al'Ilmiyyah, 1995.

Al-Husayni, Taqi>al-Dip A bu>Bakr. Kifaæah al-Akhyar fi H毛/l Alfaz\} A bi>Syuja? Surabaya: al-Hidayah, t.t.

Ibn Qudaærah. Al-Mughni. Beirut: DaßalKutub al-'Ilmiyyah, t.t.

Islam, Md. Zahidul. "Provision of Alternative Dispute Resolution Process in Islam." IOSR Journal of Business and Management (IOSR$J B M)$. Volume 6, Issue 3 (November - December), 2012.

Al-Jawziyyah, Ibn Qayyim. I'/am alMuwaqqi'ia 'an Rabb al-'A kamia. Beirut: Dasal-K utub al-'Ilmiyyah, 1996.

Za» al-Ma'a® fi Hady Khayr al-'/bad. B eirut: Daßal-Fikr, 1995.

John Winslade dan Gerarld Monk. Narrative Mediation: A New Approach to Conflict Resolution. San Fransisco: Jossey-Bass Publisher, 2000.

Khadduri, Majid, The Islamic Law of Nations: Syabani Siyar. Baltimore: John Hopkins Press, 1966.
A I-M ardi, A bu>al-H ģsan 'Ali> A/$H$ di i al-Kabiv Syarh\} Mukhtaselr al-M uzanni>B eirut: Das al-K utub al-'Ilmiyyah, 1999.

Moore, Christopher W. The Mediation Process: Practical Strategies for Resolving Conflict. San Fransisco: Jossey-bass, 2003.

Al-Ramli, Syams al-Din Muhammad ibn 'A bbas. Nihasah al-Muhtaj's ila Syarh\} al-M inhaj: Beirut: Dab alKutub al-'Ilmiyyah, 1993.

Sabiq, Sayyid. Fiqh al-Sunnah. Beirut: Daßal-Fikr, 1983.

A I-S gloupii $>$ M uhammad 'A li>Tafsis $A$ kab al-Ahkan min al-Qur'ar. Beirut: Daslbn A bbu\&, 2004.

Sahifup. Al-M udawwanah al-Kubra> Beirut: Daßal-Kutub al-'Ilmiyyah, 1994.

Said, Abdul Aziz, et.al. Peace and Conflict Resolution in Islam. Lanham, New York, Oxford: University Press of America Inc., 2001.

Spencer, David dan Brogan, Michael. Mediation, Law and Practice. Cambridge: Cambridge University Press, 2006.

Wizarah al-A wqas wa al-Syu'up alIslamiyyah. al-Mawsusah alFiqhiyyah. Kuwait: Z ał al-Salasil, 1992.

Al-Zuhgyli> Wahbah. Al-Fiqh alIslamizwa Adillatuh. Damaskus: DaralFikr al-M u'asir, 1997. 